\title{
2
}

\section{'I Will Be Travelling to \\ Kavieng!': Work, Labour and Inequality in New Ireland, Papua New Guinea}

Paige West and John Aini

\section{Introduction}

Date: 9 June

Subject: Introduction and Arrival in Kavieng 1st of July

To: Ailan Awareness

Dear John,

My name is Mary ${ }^{1}$ and I am a Master's student in Human Rights at [a big famous university in Europe]. I'm also an aspiring filmmaker. Next month, I will be travelling to Kavieng to study local forms of resistance to [a very controversial topic] in Papua New Guinea.

Mr Martin Simpson [a staff member of a big international nongovernmental organisation (BINGO)] has notified me that you will be my contact person for accommodation in Kavieng. I have

1 We use pseudonyms throughout this paper. 
therefore attached my travel itinerary and will be arriving in Kavieng on the 1st of July at 3:00 pm. He has provided me with this address for my stay: C/- P. O. Box 329, Kavieng, NIP.

I am writing to you to introduce myself and to hear if there are any things that I should plan for when I arrive - taxi, etc? My tickets are attached.

I look forward to hearing from you and meeting you very soon!

Best regards,

Mary

The emails almost always follow the above format. After the signature, the sender has attached their flight details, including their ticket receipt and itinerary. The reader of the email, the director of Ailan Awareness, a small New Ireland-based Papua New Guinea (PNG) non-governmental organisation (NGO), and one of the co-authors of this chapter, usually rereads the email several times, worries about it for two to three days. Then, they forward it on to their research partner, the other co-author of this chapter, who is a professor at a university in New York City and who now handles much of the initial correspondence between Ailan Awareness and the people whom the two of them have begun to view, over the course of their 13-year collaboration, as 'hard work'.

The sender of the email is, invariably, between the ages of 19 and 30 and from Europe, Australia or the United States (US). They are always white. ${ }^{2}$ They are either in a terminal degree program, working as a 'freelance' filmmaker, photographer or activist or travelling with the intent of developing a project to apply for a terminal degree program or make a proposal for some form of future creative work. They wish to come to New Ireland Province, PNG, to 'do work' that is in some way connected to a liberal politics of social and environmental justice, the conservation of biological or cultural diversity or some form of humanitarian-related

2 Henry (2019) has called for more a more engaged and robust study of whiteness in the literature concerned with the global movement of cosmopolitan elites. He asked that we engage a critical race theory framework to understand the structural features that uphold white supremacy and the structural inequality faced by non-white actors. Although it is focused on voluntourism, we think his call also fits for the phenomena we are examining. Moore (2019) examined issues of race and racism in her work on sciences as tourism in the Bahamas, to show the asymmetries of power that underpin sciences and that are reinforced by tourism. In an unpublished work (Aini \& West, n.d.), drawing on these scholars, we have begun to think through the racial politics of whiteness in conservation in PNG. We do not have the space to rehearse our arguments here; however, we wish to mark that whiteness matters tremendously. 
topic. These people want to 'make a difference'. They have almost always been in touch with someone working for a BINGO in PNG who knows about Ailan Awareness and their work and who has, to use a term from American gridiron football, 'punted' their request for help on to the director of Ailan Awareness. The sender, often someone who knows almost nothing about PNG, the politics between big non-governmental organisations (NGOs) and small NGOs or the financial situation of small NGOs, assumes that the PNG NGO is there to help facilitate their project. They assume this because they were told so by whoever connected them to Ailan Awareness.

The sender of the email has rarely done any serious reading of the vast body of anthropological literature concerning their topic of interest, New Ireland Province or PNG more generally. They have often read popular works about the place and its biological and cultural context there (e.g. magazine and newspaper articles). Therefore, they are unlikely to have been exposed to any sustained discussion and analysis of the in situ social conventions around exchange, reciprocity, gender relations or the local systems of prestige and honour. The sender never speaks a local language — of which there are 18 in New Ireland Province-and rarely possesses any linguistic ability in Melanesian Tok Pisin, the creole language that is the most widely used language in the country. More often than not, they are travelling to the country on a tourist visa and are paying for their visit with their own funds.

Since the 1980s, scholars have described people like the ones we endeavour to understand in this chapter as 'scientific tourists' (see Laarman \& Perdue, 1989). West has argued that scientific tourism is a form of 'alternative tourism' that allows tourists to build prestige and social capital and that it allows for complex identity work that is both self-building and guilt-alleviating (West, 2008, pp. 604-606). She demonstrated that scientific tourism is usually, in the context of PNG, a form of ecotourism and argued that people like some of the ones we describe in this chapter are enacting a form of scientific tourism (West, 2008). More recently, Moore has shown how entire tourism economies develop with 'research' and 'science' as crucial components of their infrastructure (Moore, 2019). Moore, working in the Bahamas, showed how formalised research experiences designed by universities and longstanding research institutions work to structure experience and socioeconomic-ecological life for local people (Moore, 2019). She has argued that, through examining these 
touristic forms, we can also come to understand something crucial about our current sociopolitical-ecological world-what some have called the 'anthropocene' (Moore, 2019, p. 25).

Other scholars have demonstrated the connection between research tourism and volunteer tourism (Campbell, Gray \& Meletis, 2008). While volunteer tourists may have different intentions to ecotourists and research tourists, there are certainly overlaps in intention, desire and outcome in the forms (Campbell, Haalboom \& Trow, 2007; Gray \& Campbell, 2007). Both ecotourism and volunteer tourism are big business (Conran, 2011) and big sites for scholarly analysis (Butcher \& Smith, 2015). Butcher and Smith (2015) argued that volunteer tourism is based on a sense among cosmopolitan elites that travel should be connected to something of political and ethical significance, and that people engaged in it use it as a way to engage in political action. As a form, it allows people to feel that they have shown care and 'made a difference', while at the same time building a kind of self that they see as moral, ethical and connected to a global ethic of responsibility (Butcher \& Smith, 2015). Others working in this field of analysis have argued that more analysis is required of the effects of this form of tourism on the localities in which it is enacted and that we must see the people making these trips as agents and not simply as passive, well-meaning individuals caught up in systems of capitalist extraction (Griffiths, 2016). Therefore, we see this chapter as connecting to the tourism literature.

In this chapter, we analyse these kinds of requests and the social and economic interactions and relations that enable them and stem from them, using four different lenses. First, we locate this kind of request within a broader field of structural inequality and patron-client relationships that envelop small NGOs in places like PNG, by describing the history of Ailan Awareness and its relationships with BINGOs. Further, we show how this history creates the conditions of possibility for both the 'punting' of the requests and the practice of saying 'yes' to the requests by Ailan Awareness staff. ${ }^{3}$ Second, we describe in detail the form that these requests

3 We are highly attuned to the extreme sensitivity that BINGOs experience when scholars and practitioners write about them. We do not write about them lightly and we are not 'blaming' them for anything. Rather, we are focusing on their structural position in systems of inequality in PNG. We could also highlight the structural position of other kinds of institutions (e.g. churches, government offices, universities or businesses) in systems of inequality in the country. This would also not be about 'blame'. We do not intend to hurt the feelings of the BINGOs or their staff with our analysis. Rather, we attempt to illuminate a system that is both inherently unequal and enduring. 
manifest through communication, and we expose both the naivety and the privilege behind them. We do this to clarify the structural conditions that allow for the production of inequality that we demonstrate throughout the chapter. Next, we show the forms of work and economic expenditures required to meet these requests and the social and economic debts incurred in meeting them. We contextualise this in a brief discussion of labour and conservation more generally. Alongside this, we examine the mobilisation of networked social relations of obligation and reciprocity required and expended when this sort of request is met. Finally, we tie all of this back to the enduring structural inequality that forms the conditions of work for small NGOs and the continuation of a kind of labour-intensive patronclient relationship between small and large NGOs. We do not analyse the motivations that drive these individuals to come to New Ireland; therefore, this is not an ethnographic study of their touristic desires. Nor do we analyse the identity work that these individuals undertake during and after their visits. Our interest is primarily the inequality that is exacerbated by their visit-inequality that they may well not understand prior to, during or after their visit.

The literature on inequality in PNG has focused on inequality in relation to traditional, yet changing, local sociocultural contexts (Kelly, 1993; Strathern, 1982); in relation to the colonial economy (Fitzpatrick, 1980), in terms of gender relations (Beer, 2018; Josephides, 1985; ZimmerTamokoshi, 2016) and in access to education (Johnson, 1993), knowledge (Ryan et al., 2016) and development (Connell, 2005). Gewertz and Errington (1999) have shown how various existing inequalities intersect with the emergence of class position, status and ideology in a postcolonial context. Wardlow (2006) has shown how historic and entrenched sociocultural inequalities, such as those mentioned above, intertwine with new forms of labour and work to produce cultured forms of envy, resentment and desire. ${ }^{4}$ More recently, Roberts (2019b) has connected an analysis showing that large-scale logging and agricultural development increase local inequalities and disproportionately negatively affect women and lower-status individuals to an analysis of the structural inequalities that allowed for the issuing of the special agricultural and business leases that resulted in the same logging and agricultural projects. This could be read simply as an enduring anthropological interest in forms of difference

4 For a broad overview of the anthropological treatment of inequality in PNG, see Bainton and McDougall (this volume). 
and their emergence in PNG. ${ }^{5}$ However, Fabinyi, Foale and Macintyre (2015) have shown that concerns about the emergence and entrenchment of inequality are paramount in the minds of Papua New Guineans. They demonstrated that, without a doubt, understanding 'local priorities' regarding inequality and its redress should be a key goal of scholarship, policy making and development priorities (Fabinyi, Foale \& Macintyre, 2015, p. 472). Our interest in inequality, conservation organisations and people who are 'hard work' follows this literature and, in particular, the arguments that understanding the relationship between individual inequality, how Papua New Guineans see and understand it and structural inequalities that are underpinned by larger, non-local relations of power, is important to Papua New Guineans.

5 This brings us to the question of where anthropologists fit into our analysis. Anthropologists have been coming to what is now New Ireland Province since the German colonial period of the 1880s. They have extracted objects such as Malagan funerary pieces, information such as kinship diagrams and land ownership charts and knowledge such as detailed descriptions concerning ontological propositions about what is, what can be and what will be. Little of this extracted material has ever been adequately repatriated to New Ireland and the anthropologists who have extracted it have benefited tremendously through the acquisition of paid positions as scholars, promotion to tenured positions and esteem notoriety in their field. Some of these anthropologists have maintained deep, enduring and complex social relationships of exchange and reciprocity with the people they have worked with. They return to their field sites frequently, maintain close communication with 'communities' and individuals when they are at home (rather than in PNG), pay for young people from the places they work to go to school or enter trade training programs, write grant proposals for community development projects and, more generally, sit comfortably within longstanding, enduring networks of reciprocity and exchange. Further, some of their anthropological work does 'benefit' the communities and individuals who contributed to it. These anthropologists seem to understand that their accumulation of both financial capital and social capital is tied to their extraction of material from New Ireland; therefore, they understand that their social relations there must be maintained and reciprocated adequately. However, some anthropologists do not seem to understand this point; consequently, their work serves as another form of extraction. Indeed, this is the case for all of what is now PNG. In this chapter, we do not have the space to articulate and examine the complexities of what we conceptualise as 'the debt that can never be paid' that anthropologists incur with their research in PNG. In a longer work, we would tease out the difference between knowledge production, something that we value and believe that anthropologists contribute to in both positive and negative ways (West, 2016), and pure knowledge and labour extraction-what we think happens with requests like the ones we will describe in the rest of this chapter. Suffice it to say, we do not believe anthropologists are innocent; however, we do believe, as our analysis is focused on a different kind of actor (one who visits New Ireland once and often never has anything else to do with the place), that a deep analysis of anthropology is beyond the scope of this particular paper. 


\section{Inequality, BINGOs and Ailan Awareness}

In 1993, after working in and around international conservation NGOs and the National Fisheries Authority (NFA) as fisheries specialists and developing a critique of their practices, three young men from Lovongai Island (New Hanover) founded Ailan Awareness. Their initial goal was to engineer a new approach to local marine conservation that diverged from the norm of externally generated conservation goals that were developed, implemented and assessed by outsiders to one that grounded all new projects within the context of local sovereignty over resources, conservation initiatives and projects and the potential future of resources (Aini \& Nason, 2016; Aini \& West, 2018; West \& Aini, 2018; see also Foale, this volume). In the 1990s, the founders of Ailan Awareness developed what has come to be known as 'The Road Show'-a process where Ailan Awareness staff go to coastal communities to conduct 'conservation awareness', helping rural and remote people to understand some of the science behind observable changes in coastal and marine biophysical environments and introducing them to scientific management techniques that were thought to help mitigate these changes. Employing men and women from New Ireland who spoke the local languages, understood the local political and social structures and who were, in most cases, socially embedded into the communities through the long tentacles of kinship relations and obligations across the region, the Road Show proved to be a very effective way to convey the goals of the Coastal Fisheries Management and Development Project (CFMDP), a project funded by the PNG government and various ocean conservation-related projects. During the following decade, word of the success that CFMDP was finding through their partnership with Ailan Awareness spread quickly in PNG. To say that there was a frenzied buy-in from BINGOs focused on marine conservation and from the national government for the methodology developed by Ailan Awareness would be an understatement. ${ }^{6}$

\footnotetext{
6 The NGO currently supports environmental conservation efforts in over 20 local communities (projects that were crafted by community residents rather than outside NGOs), supports a project developed by local master carvers focused on revitalising Malagan carving techniques and traditions and passing those traditions on to young people, conducts scholarly research on topics from climate change to Special Agricultural Business Leases (SABLs) and land grabbing and runs a small school focused on teaching at the nexus of local epistemology and ontology and the scientific method. Over the past 25 years, the NGO has been locally successful and has become internationally recognised for both its conservation work and its radical anti-dispossession stance and practice (Gokkon, 2018a, 2018b).
} 
The late 1990s and early 2000s comprised the heyday of CommunityBased Resource Management (CBRM) and Integrated Conservation and Development (ICAD) projects (Halvaksz, 2020; Van Helden, 1998; Wagner, 2007; West, 2006). These projects were generated in the Global North, based on conservation goals that had been identified by scientists working for BINGOs and in partnerships between those organisations, multilateral institutions (e.g. the United Nations) and big international lending institutions (e.g. the World Bank). The 'country programs' of the conservation BINGOs then carried out these projects locally. Part of the ideology driving them was the notion that previous conservation project failure, a chronic issue for conservation-related interventions, could be staved off by incorporating 'local people' into the management of biological diversity. Soon, Ailan Awareness had more work than they could manage. Everyone wanted a local team to go out to rural sites and 'teach' people about conservation, in general, and garner 'local participation' in their specific project. Ailan Awareness got swept up in this and performed well in terms of assisting NGOs and others to facilitate their projects. However, their vision - that of an organisation that also worked to educate outsiders regarding the importance of full local sovereignty over biodiversity conservation projects-was not fulfilled.

Throughout the late 1990s and early 2000s, most of the BINGOs working in island PNG wanted to engage Ailan Awareness to do CBRM and ICAD education. However, they were only willing to pay them for services rendered per project; they were unwilling to support them further by funding organisational operating costs such as office rent, computer support or salaries for staff at times when there were no projects to be done (see West, 2016). This put the founders of Ailan Awareness in an awkward position - they needed the work from the BINGOs to continue to do the unpaid project work that Ailan Awareness was undertaking with communities; therefore, they felt that they had to take the work offered to them. Essentially, a 'patron-client' relationship developed between the small NGO and several big organisations-Ailan Awareness became a service provider to the very kinds of projects that John, Miller and Michael, its founders, had initially founded the organisation to counter.

Through their success in undertaking and completing contract work for the BINGOs, Ailan Awareness became a kind of cover for BINGOs, so that they could say to their funders-organisations that were increasingly nervous following several well-publicised critiques of such organisations' lack of local engagement and local partners (see Chapin, 2004) - that 
they had engaged an indigenous NGO as an equal partner in their work. However, these partnerships were incredibly unequal. Ailan Awareness was only engaged to do waged contract work; they were not consistently funded at a level that allowed for them to adequately maintain an office, a staff, a vehicle or a boat. All of these are required to be a functioning NGO and, at the time, were being paid for through the Gillet Preston and Associates, Asian Development Bank (ADB) and NFA partnership. However, with Ailan Awareness listed on major grant proposals to multilateral organisations and major global conservation funders, the big NGOs were able to garner the vast majority of the money that flowed into the area for marine conservation. ${ }^{7}$

There are three notable exceptions to this pattern. First, the NGO has a longstanding relationship with archaeologists from the University of Papua New Guinea and has collaborated extensively with that work across the province. Second, since 2005, the ADB partnered with the NFA of PNG and hired the fisheries consultancy firm Gillet Preston and Associates to manage CFMDP; they, in turn, contracted John Aini and Ailan Awareness to adapt the Road Show to the needs of their project. They funded full costs of running the NGO for several years and allowed the organisation to take some of the support work offered to them by the BINGOs. They did this because they believed that the work being done in New Ireland by the BINGOs formed a positive contribution to marine resource conservation. This period of funding was the only time in its history that Ailan Awareness has not had to rely on the BINGOs and the structural position that they hold in the world of international conservation. Finally, since 2007, the NGO has partnered with anthropologists, ecologists and lawyers from Barnard College and Columbia University to expand the NGO's focus to include projects that work to maintain local sovereignty over both biological and cultural diversity through revitalisation projects, local awareness projects, research project partnerships and locally generated but internationally supported small-scale conservation initiatives.

During this time, due to their success with this contract work, another form of relationship emerged between Ailan Awareness and outside institutions; they became known as a 'fixer' for others in New Ireland. BINGOs turned to them to help facilitate their projects logistically,

7 This also happened across the country simultaneously, in relation to national terrestrial conservation NGOs and projects (West, 2016). 
even when they were not engaged to do the Road Show, specifically, or 'awareness', more generally. BINGOs also began to ask Ailan Awareness to provide them with logistical support when they held organisation meetings and workshops and when they brought potential donors, journalists and filmmakers to the area. Multilateral institutions began asking them to assist with organising trips for visiting dignitaries. Diplomatic missions began asking them to organise visits for ambassadors, international diplomatic core visitors and others to rural villages across the region. Media outlets such as the BBC, the New York Times and The Guardian, unaffiliated film crews from China, France and the United Kingdom (UK) and global justice organisations, such as Global Witness and Canopy Watch, began contacting Ailan Awareness when they wanted to send a group or an individual to the area, to do a story, find a story or gather data about logging, mining or fishing.

These ongoing requests require time, money, networks, work and labour. Sometimes, Ailan Awareness is reimbursed or compensated for the money and labour expended in fulfilling these requests; however, more often than not, this does not occur. They are never compensated-how could they be-for the forms of obligation that they amass across the province when they call on their personal kinship obligations and networks to help meet these requests. They are never compensated for the expertise that they provide regarding local social practices and customs and local marine tenure organisation. Outsiders assume that their requests are minor and do not think through the kinds of expenditures that are involved in setting the conditions of possibility for their work in or visit to New Ireland.

A recent example of this kind of request and the associated labour is as follows: Ailan Awareness was contacted by a large group of researchers through one of the international embassies in Port Moresby and asked to help facilitate a visit to New Ireland by several scholars from an institution that had contacted the embassy for help. They wanted to come to New Ireland to do a pilot study for future possible research. The embassy contacted Ailan Awareness through one of their longstanding research partners, who suggested that Ailan Awareness could help the scholars negotiate prices for transportation and accommodation on the island during their research period. Ailan Awareness agreed to help. In addition to helping to secure transportation and accommodation, they paid to clear access for the scholars to the villages they wanted to visit and paid village elders for their time spent guiding the visitors. Further, upon their 
arrival in New Ireland, Ailan Awareness provided the scholars with food, beer and a 'traditional hornbill dance', during their brief visit to the Ailan Awareness office in Kaselok Village.

During their time in New Ireland, the scholars asked a crew of local men to assist them with their work. Ailan Awareness staff working on that crew reported that 'we went without lunch in the bush for two days while they ate cans of canned tuna and bully beef'. Eventually, John Aini organised some of his distant relatives to provide the workers with wild cassava harvested on their land. He was able to call on longstanding obligations and debts that people had to him and Ailan Awareness. The people he called on reciprocated in socially appropriate ways and, in doing so, transferred debts of reciprocation back towards John and Ailan Awareness.

Ailan Awareness was never reimbursed for the cash that they spent to facilitate this visit. Nor were they compensated for the labour they provided-neither the physical labour nor the more nuanced labour of mobilising kinship relations to arrange their accommodation, negotiate their transportation to and from their site or the work it took to negotiate access to the site. This kind of work was rendered invisible when it was described as 'island hospitality'; in fact, the seemingly hospitable relations of the Ailan Awareness staff will demand that that hospitality be reciprocated over and over again for the foreseeable future. The relatives will demand that Ailan Awareness and its staff contribute to funeral costs and other cultural demands for years to come because they assume that Ailan Awareness received extensive financial compensation from the group.

Many of the kinds of requests illustrated by the above example are part of what the Ailan Awareness staff have come to view as part of the price of doing work in PNG. Their structural position is such that larger institutions such as BINGOs, government offices, multilateral institutions and diplomatic missions hold sway over many of the resources that the small NGO requires to continue its work. 'Helping' them with these kinds of requests may result in the amassing of both good will and obligation from the requestor to Ailan Awareness. The staff of Ailan Awareness reads and orders these requests through a Melanesian social order of exchange, obligation and kinship relations. They assume that their work will result in strengthening these kinds of ties. They also assume that 'the good will' they will amass with actors and organisations that do not readily participate 
in Melanesian forms of sociality-what sociologists who do not work in Melanesia might call 'social capital'- has the potential to garner actual financial capital in the form of grants, fellowships and support for the small NGO, its student interns and its national staff.

The group of international researchers mentioned above, for example, built good will between the NGO and the embassy and, given that the embassy had publicised the NGO's work in the past, their expenditure was seen as part of a networked series of social relations. Additionally, similar visits from Global Witness resulted in a series of reports that exposed illegal logging on Lovangai and the relationship between that logging and SABLs, creating the conditions for a parliamentary inquiry into the situation. Further, a visit from the US Navy strengthened partnerships between Ailan Awareness and researchers at the University of Papua New Guinea. Finally, a recent Canopy Watch visit resulted in a beautiful website that focused on the various social and ecological crises currently taking place on Lovangai. We interpret these requests and their costs as providing benefits to local communities and the mission of Ailan Awareness. They are part of the ongoing, enduring sociality of reciprocity in both New Ireland and PNG, more generally.

Requests such as the one we outlined at the beginning of this chapter are different. They come from individuals who will likely come to New Ireland once, who will never return any of their findings (or film or images) to the people or the place and who will usually never contact anyone who facilitated their visit again after that visit. After over a decade of meeting these kinds of requests, Ailan Awareness has come to the conclusion that no one in PNG benefits in any discernible way from the significant work they require; therefore, they are a pernicious element of structures of inequality that keeps the NGO from doing the work they wish to do. Further, we argue that these requests perpetuate a series of deeply troubling, racialised hierarchies of inequality.

Below, we provide one example of the course taken by these kinds of requests and the visits. We wish to stress that this one example is of a type that occurs repeatedly. This type begins with an initial email, moves through a period where Ailan Awareness provides information, then into a period in which they discover that the requestor knows nothing about New Ireland, resulting in a social 'mess' and a host of debts to be paid by Ailan Awareness. What follows will be uncomfortable reading for some. Some may think something along the lines of 'oh, but they 
meant well, they are just young and naive'. We follow Professor Chelsea Bond, a Munanjahli scholar who recently argued that thinking of, talking about and casting people as 'well-meaning' both covers all manner of historical sins and reinforces contemporary white privilege (Bond \& West, 2018). We extend this line of thinking to demonstrate how these kinds of requests reinforce structural inequality.

\section{Visiting New Ireland Province to 'Do Work'}

The biophysical environment in which Ailan Awareness works is under threat from a variety of internationally driven processes, from global climate change to illegal logging and fishing, the growth of oil palm plantations and mineral resource extraction through gold mining (Nason, 2018; Roberts, 2019a). New Ireland Province may be thought of as a microcosm of all global threats to biological diversity. Therefore, it draws the attention of liberal subjects who wish to study, document and counter what they perceive as environmental injustice. New Ireland Province also sits squarely in that zone of Euro-American-Australian settler-tourist imagination that might be called 'a tropical paradise' (Foale \& Macintyre, 2005). The area is spectacularly beautiful, the people are welcoming and kind, there occurs very little violence or crime, and it is part of PNG, a place that also occupies a particular kind of place in the consciousness of outsiders in terms of how visiting it makes them see, feel about and cast themselves. From the colonial period (Stella, 2007) to the present (West, 2016), visitors have used their visits to PNG to fashion themselves as intrepid explorers. Following their visits, visitors increasingly cast themselves as valiant voices for global equality and environmental justice who are, due to their experiences in the country, more aware of global inequality than others (West, 2012, p. 178). These are the kinds of visitors whose requests we examine in the rest of this chapter.

Each visit begins with the initial email. In the time between the initial email to Ailan Awareness and the person's arrival, numerous other emails are also sent between Ailan Awareness staff, Paige West and the impending visitor. Some of these, if the person is a student, are invariably between West and the student's supervisors. Some involve the project staff person at the BINGO that has suggested Ailan Awareness might help them with their visit. Some readers may wonder why Ailan Awareness do not just ignore the initial email. We stress that the people emailing have always 
been in touch with someone in a structural position of power (in relation to the small NGO) and that, more often than not, this person works for a BINGO upon which, at some point in time, the small NGO has relied for project funding. Therefore, the director of the NGO feels obligated to answer the email; further, to say 'no' to requests makes him feel both 'ashamed' and that he is not maintaining proper social relationships. This is, for him, an untenable existential crisis - if he is not willing to 'help' and return previous social connections, he begins to question his identity and his role in the world. The anthropologist feels that it is not her place to say 'yes' or 'no' to anyone when it comes to their desire to come to PNG, because she is also a 'visitor' to the country, albeit a longer-term one. Although they have a long-term research partnership and through customary obligations and affects are now 'brother and sister', she also feels strongly that everything that Ailan Awareness does, or does not do, should be the decision of Ailan Awareness; therefore, she always follows her collaborator's lead. Further, if the person emailing is a student, she feels an obligation to help because she knows that people help her $\mathrm{PhD}$ students when they begin to develop their projects (although she hopes that they behave in radically different ways to those that we outline below).

In a recent case (that is distinct from the one we described at the beginning of this chapter), in which the sender emailed Ailan Awareness three weeks before he was to arrive (having already purchased his airline tickets), our initial reply, following multiple emails between New Ireland and New York, asked the sender for more information about his proposed 'project', his funding and his adviser, in addition to his plans for accommodation and if he had been in contact with any of the people in the communities that he planned on spending time with during his visit to New Ireland. The sender, a first-year master's student who we will call 'Brian', replied to our initial message, beginning a series of messages in which we worked to discern his expectations, how he aimed to pay for his visit to New Ireland and the level of engagement he had had with the community members that he wanted to come and spend time with. Below, we give further details of our interactions with him and his advisers, because these mirror how the vast majority of these requests and interactions unfold.

Brian, who had contacted Ailan Awareness only three weeks prior to his planned arrival, replied to Paige West's first email, the one that asked the questions given above, five days after it was sent, with a very friendly email that offered more detail about his proposed project (including his research questions), identified his adviser and gave us a link to their 
research page. He also advised that his project was to be funded 'privately', that he had not booked a hotel because he intended to stay at the Ailan Awareness researcher bungalow, which he had heard about through the BINGO with whom he had been in contact, and that he had not been in touch with any of the communities that he was planning to visit or work with. His project, which will not be described in detail (to protect his anonymity), entailed the examination of an issue that intersects with questions of land ownership, resource extraction, governance and the role of civil society and transnational activists in natural resource-related conflict and environmental conservation.

Paige and John discussed Brian's email on the day of receipt and replied the following day, with a list of five things that they thought he should be aware of before coming to New Ireland-please keep in mind that he had already purchased his airline tickets from the UK to New Ireland before he sent his initial email to Ailan Awareness. Our email to him comprised what we have come to view as 'the provisioning of information'. First, we explained to Brian that the Ailan Awareness bungalow funds the Solwara Skul, an Ailan Awareness project, and that the rate is USD 150 or USD 100 per night, depending on whether food and transportation are included; further, the bungalow was, unfortunately, already rented for part of his prospective stay in New Ireland. Second, the bungalow is located $13 \mathrm{~km}$ from Kavieng town; therefore, he must be willing to ride local buses to and from town if he decided to stay there without paying the additional USD 50 per night. Third, the area of his planned work is over $80 \mathrm{~km}$ from town, and much of the required travel would be via public transportation on very poor quality roads. Therefore, we urged Brian to connect with the BINGO with whom he had already been in contact to form a plan for his transportation to the area. Fourth, we reminded him that people in New Ireland speak 18 different languages, in addition to Melanesian Tok Pisin; although people in town speak English, he would need to engage a translator for the entirety of his work in the more rural parts of the province if he did not speak Tok Pisin (which he did not). Finally, we gave Brian the names of several anthropologists who had worked in the communities he wanted to visit, in the hope that he would contact them to learn more about the local history and custom. We also reminded him that local people have the right to refuse researchers who wish to conduct work in their communities; this had already been the case with some recent attempts to research his topic of interest in the area. 
Brian replied the next day with a short email that thanked us for the information we had provided and informed us that he had booked alternative accommodation for those dates that the Ailan Awareness bungalow was unavailable, that he would be contacting the anthropologists we suggested and that he would contact the BINGO that had connected him with Ailan Awareness. Brian did not mention the bungalow fees we had quoted; therefore, we emailed him again to remind him of the costs and request that he inform Ailan Awareness if he intended to book it for the first 15 days of his stay. He replied that he would like to book the bungalow, including the additional transportation and food fee, and asked how he should pay for the accommodation. Paige replied that he must pay in kina, which could be obtained from any ATM in Port Moresby or at the airport on the way into the country, but that the ATMs in Kavieng were both broken; therefore, he must organise the money before he arrived in New Ireland. We also attached an invoice for USD 2,250-the total cost of his stay at the Ailan Awareness bungalow. Four days later, Brian replied, asking if he would have 'streaming internet' in the bungalow. This request marks the moment that such interactions shift to what we now call the 'knowing nothing phase'.

Paige replied to explain the nature of internet access in the country and the best way to obtain a SIM card for his phone at the airport in Port Moresby, including information about the national provider, Digicel, and its fee structures. Four days prior to his scheduled flights to PNG, Brian emailed to tell Paige that he had encountered 'a little predicament' and required some help. He was to be travelling over a bank holiday and would not be able to access a bank in the UK with enough time for that bank to order and prepare the cash. He was worried about being able to obtain enough kina in either Australia or Port Moresby before arriving in Kavieng, because his bank had recently imposed a withdrawal limit on his account. He asked if he could bring US dollars or make a bank transfer to the Ailan Awareness account. Paige immediately replied that he could transfer funds directly to the Ailan Awareness account, including the account details and copying in John Aini and Ailan Awareness. She then told Brian that he must do this prior to his arrival because John had to buy supplies, pay a female relative to come from a village site to serve as the cook, pay another to come to serve as the cleaner, pay for the car he had to hire to transport her (because Ailan Awareness does not have a vehicle) and pay for the boat to bring the driver and one security guard from Lovongai. During this time, Paige and John remained in contact with one 
another regarding the situation, in addition to Brian's advisers, who were curtly apologetic about his lack of preparation for the visiting but did not provide any promise of support in terms of rectifying the situation.

Brian's final email to Paige prior to his arrival in New Ireland arrived on the evening before his international flight and explained that he would try to obtain the money before arriving in Kavieng. However, that same evening, he also emailed John. Those emails began with a request for the Ailan Awareness bank account details, which had already been supplied by Paige. At 10:14 pm, John provided the account details, followed by the Society for Worldwide Interbank Financial Telecommunication (SWIFT) code (10:19 pm). At 10:23 pm, Brian requested the bank's address. John replied at 10:24 pm; Brian replied immediately with a message saying that the postal code for the bank was required (10:24 pm). At 10:33 pm, Brian sent a message that said, 'Thank you very much. I have now made the transfer and my bank has notified me that the amount will be transferred to you on Tuesday', closing with a pleasant 'sincere apologies'. Over the next seven days, no further emails were received from Brian. In New York, Paige assumed that the bank transfer had been processed and that all was well—unfortunately, it was not.

Brian arrived in Kavieng and was transported from the airport to the Ailan Awareness compound and given access to the bungalow. He was also offered the extraordinary hospitality that is common during a visit to a PNG village. The Ailan Awareness compound is in Kaselok Village, a Tigak-speaking village along the Boluminski highway; the village sits between the highway and the Pacific Ocean on the east coast of New Ireland. Ailan Awareness has been situated on land owned by people from Kaselok since 2001 and has hosted hundreds of NGO-related guests. Residents understand the social conventions that European, American and Australian visitors desire when they first come to a rural (or peri-rural) place in PNG; for example, that visitors do not want children, pigs or curious onlookers hanging around their accommodation or locals dropping by with questions or to share stories or food. Residents also understand the visual iconography of 'paradise' that visitors desire, and they work hard to provide this to them. The bungalow itself is magnificent. It was constructed in the traditional style of Lovongai (New Hanover), sits 5 metres from the beach and looks out over a fringing reef. It has a bedroom, an equal-sized veranda, screens on the windows and access to a private bathroom and shower block. 
Brian stayed for only five days at Kaselok, before informing John and his family that he was moving to 'a more comfortable and cheap place'. This departure shamed everyone at Ailan Awareness; they felt terrible that Brian had not found the accommodation acceptable. Additionally, John and others had to spend time discussing this with the residents of Kaselok, who also felt shame due to the early departure. On the day he left Kaselok, John and his family took Brian into Kavieng; John assumed that he would pay for his accommodation, food and transportation for those five days prior to departing because the transferred funds still had not appeared in his bank account. Brian assured John that the transfer had been made and that the bank was just slow. The next day John went to the bank and waited 112 minutes in line to check on the transfer-still, it had not arrived. That same day, while at a hotel in Kavieng, Brian emailed John to say that he required an International Bank Account Number (IBAN) code for the transfer. John replied that this not the case in PNG; rather, banks require a SWIFT code. Once again, he provided all the bank details that Brian would need to complete the transfer.

The following day, Brian emailed Paige to inform her of delays with the payment, saying that he had tried to make the bank transfer twice but had been declined both times. The next day, he emailed John again with an attached screenshot showing that he had entered John's bank details. However, this was not a receipt for money that had been sent-it was simply a screen showing the entered details and text that read 'Hit enter to send funds'. Brian also included an apology to John, assuring him that the bank details had been worked out and the transfer was imminent. This was John's last email from Brian-to date, Ailan Awareness has received no funds from Brian. John finally admitted to Paige that Brian had never paid, saying, 'I felt ashamed to ask for it anymore'. This shame was compounded by the shame that John, his relatives and the residents of Kaselok experienced when Brian departed early for a more 'comfortable' location.

\section{Work, Labour, Expenditure and Inequality}

We view 'work' as both the creative somatic refashioning of some materials in the world and creative engagement with others to maintain, enhance and create social networks of obligation and exchange. We see 'labour' as the measure and analysis of 'work' when it is tied to the capitalist 
system of production. Anthropologists have illustrated the work and labour required to create the idea of a pristine environment in need of conservation (Foale \& Macintyre, 2005), the ideological work and labour that contribute to the crafting of conservation agendas (see Carrier \& West, 2009), how the work and labour of designing conservation agendas has shifted from the purview of scientists to economists (Cleary, 2018) and the work and labour that are expended in trying to align local, regional and international conservation agendas (Wahlen, 2013). Anthropologists have also discussed the social and economic disparity between local and non-local conservation workers and conservation NGO employees (Hathaway, 2013; Lowe, 2006; Vivanco, 2007; West, 2016). However, very few have examined, in detail, the labour that contributes to the success of conservation interventions on the ground.

Genese Sodikoff provides an exception; she has tracked the labour of manual workers in Madagascan conservation projects (Sodikoff, 2009, 2012). She showed that workers perform a range of duties related to monitoring reserve boundaries, cataloguing species, maintaining infrastructure, working with local communities to help them understand conservation rules and working as guides for tourists and scientists. Without such workers, conservation projects simply could not exist, nor could the scientific 'discoveries' that feed back into the international valuation of internationally funded parks, reserves and conservation areas. Sodikoff examined the creation of value in the forests, the effects of hierarchy and highlighted 'the mundane tasks that have made possible the acquisition of certain types of knowledge and the evolution of certain philosophies of nature' (Sodikoff, 2012, p. 7).

Catherine Wahlen (2013) has argued that we must do more to understand the inequality that both underpins local, national and international conservation staff and employee interactions and the inequality that emerges through the course of conservation projects. We agree with Wahlen, believing that, in the context of PNG, one appropriate starting point is to analyse the 'work' that emerges in the wake of requests such as Brian's. Why, given that Brian's trip to PNG was not part of a broader conservation project, do we connect his trip to this broader field of analysis? We do this because he was 'punted' to Ailan Awareness by a BINGO and because he later wrote a master's thesis that focused on the extremely controversial topic that he initially proposed. In this thesis, he offers conservation and activist solutions to the problems generated 
by the topic; therefore, his trip fed back into the work of fashioning external conservation agendas for the country and the work of his own self-fashioning as a scholarly voice in conservation.

During the five days that Ailan Awareness staff were responsible for Brian's visit, they undertook a range of activities that we might consider work. However, this work actually began prior to his visit:

When I receive an email, the cost and the stress start. First, I have to run around looking for a good internet connection to answer the email. Then, I have to pay for the data to send the emails. Every bit of email costs money to send and receive. If I can't find a spot in Kaselok, I have to go into town where the reception is better. This costs money (email costs and fuel) as well as time.

Then, once I have replied, if we decide to help the person, I start the organising - getting in touch with people, my relatives and the Ailan Awareness contacts to organise for the person to visit the place they want to visit or learn about the topic they want to learn about (e.g. logging, SABLs, shark calling, undersea mining), organising accommodation at Solwara Skul bungalows if they are to stay with us in Kaselok or getting quotes from hotels in Kavieng for visitors wanting to stay in town, making calls to organise boats and trustworthy skippers, physically seeing boat owners and making sure that their engines are trustworthy, securing a hire care if I am not going to be their driver, finding the best prices for fuel and then paying deposits for everything or asking for credit all over town to secure the reservations. Then, I have to spread the word with calls and texts or physically going to see and to make the communities aware that they will be visiting. This is before anyone even arrives.

After various details are confirmed, financial expenditures begin. Below, we give a rough estimate for how much a five-day stay, such as Brian's, costs Ailan Awareness:

\section{Fixed Costs (all given in PGK)}

Internet service $(600 \mathrm{MB}): 40$

Electricity (fan, lights and refrigerator): 40

Phone service: 50

Ailan Awareness support staff travel: 860

8 The cost for Ailan Awareness support staff to travel from Lovangai to Kaselok for the visit is PGK 100 (for one round trip). We use six staff for each visit (two cooks/cleaners, two carriers/general workers, one security guard and one guide), which incurs a total of PGK 600. 
Pre-visit cleaning materials and bungalow dry goods: 80

Hire car: 700

Fuel: 300

Food for staff: 930

Total: PGK 2,140 (approximately USD 637)

\section{Salary Costs}

Salary for support staff (600 per day): 3,000

Ailan Awareness director salary: 400

Total: PGK 3,400 (approximately USD 1,012)

Prior to Brian's arrival, Ailan Awareness paid the fixed costs of USD 637. Recall that, in our initial communication with Brian, after he had settled on staying with Ailan Awareness for 15 days, we sent him an invoice for USD 2,250. Therefore, over the course of five days, Ailan Awareness spent almost one-third of the amount he agreed to pay but never paid. This amount represents approximately 1.7 per cent of the NGO's total operating budget for 2018. ${ }^{10}$ Further, because Brian never paid his bills, none of the Ailan Awareness staff were paid for the work they did during his visit. Therefore, following Brian's visit, Ailan Awareness were USD 637 out of pocket, because he did not pay his fee, in addition to the debts incurred by not paying the support staff salaries. This USD 637 was not part of any approved project budgets for 2018; therefore, John Aini was required to reimburse the NGO for these costs from his own personal funds. This amount represented 4.25 per cent of his total annual salary for 2018.

Further, these calculations do not capture other forms of expenditure mobilised for Brian's visit. For example, that unpaid PGK 3,000 in salary for support staff (that Ailan Awareness was unable to pay because Brian never paid them) created both a financial debt and an enormous social debt. The NGO will pay for this repeatedly, in terms of having to reciprocate the time and work outlaid by these staff members. Ailan Awareness also mobilised kin and broader social networks in the region of New Ireland that Brian wished to visit. Prior to his visit, Ailan Awareness

9 We provide three meals per day: approximately six packets of rice (PGK 4 per packet $=$ PGK 24), three cans of canned fish (PGK 5 per can = PGK 15), one packet of sugar (PGK 6), one packet of coffee (PGK 9) and six bundles of greens (PGK 12). The total cost is PGK 66 per person per day. 10 For the 2018 fiscal year, the total Ailan Awareness operating budget (for which they had funding) was USD 37,500. This includes all NGO expenses (including operating costs and salary) and the amount was funded by the Christensen Fund. These are all directed funds, meaning they are project related and not part of a general operating budget. 
staff visited those communities and gained permission for him to visit. This entailed the amassing of obligations to people in those communities, which will be repaid in the future via contributions to weddings, funerals, births and political campaigns. Ailan Awareness will also have to host members of those (very remote) communities, if they arrive in Kavieng with no place to stay, and loan money to elders from those communities when they require bus fares back to their villages. They have, in other words, incurred social debts that are impossible to quantify and will be repaid over the coming years.

Of these costs, one Ailan Awareness staff member said:

Our visitors don't know these costs, how should they know, who would tell them? I am ashamed or they might think I am just another Papua New Guinean trying to rob them or I don't want their stay to be expensive. A lot complain about the airfares, saying it's so expensive travelling in PNG, of which I agree. But they don't ... they think sometimes ... when I arrive at the airport in a car to pick them up, what do they think that the car runs on? How do they think we pay for that? And they sit on the veranda of our bungalow and they say how beautiful it is and how nice it is to have a fresh and clean bed, cooked food, lights for them at night. Did it just happen? Is it a miracle?

Over the course of any visitor stay, Ailan Awareness staff perform various kinds of work, some of which may be thought of as 'labour' that can easily be tied to and valued through a monetised system of social relations. First, the staff spends time going to places to set the conditions for the visitor's visit. This work can, and should be, valued at an hourly or daily rate. For example, if a staff member spends a day driving to the coast to organise for a visitor to go and shoot footage in a remote village, she or he should be paid for it. Second, staff spend money to prepare for the visitor's arrival - they hire a cleaner to replace the linen and ensure the guesthouse shower and bathroom faculties are clean and in working order. They hire women to come and cook for the guest and purchase staple foods such as rice, cooking oil and salt. They rent a boat or a car to transport the visitor, which must be paid upfront. Each of these aspects is easily monetised. Again, you might ask, 'why doesn't Ailan Awareness just have a rate sheet to give to people?' In answer, we ask the reader to consider Brian, who was provided with this information and still failed to pay. While his is an extreme example, it is often the case that a visitor is unaware of any of the kinds of work discussed in this section, even when it occurs around 
them. The labour required to make their stay possible is invisible. Visitors tend to assume that everything they observe occurring is part of 'island hospitality' or that it is covered by the rental costs of the Ailan Awareness bungalow. We cannot express this enough-PNG is an extraordinarily expensive country. The daily rental costs of USD 100 (PGK 300) or the USD 150 (PGK 450) only cover the labour costs (cooking, cleaning, power and water) and the transportation (for the higher fee) in and around Kaselok and Kavieng. Everything else that we have outlined, all other easily monetised forms of work, is additional.

Each visitor also generates other forms of work, forms that are less easily monetised. For example, if a visitor wishes to go to a village down the east coast of the island to spend a month collecting footage for a film, Ailan Awareness staff must visit the village at least once (but often more than once) before the visitor arrives to explain who the visitor is, what they will be doing, why they will be doing it, where they wish to do it and how the information gained will be used. The staff must then secure access to the sites the visitor wishes to visit, which almost always entails multiple conversations with multiple family groups and leaders. This work relies on existing social relations between Ailan Awareness and the residents of the village and extensive 'local knowledge' of the social and political factors at play in each locality. This specialised knowledge is immensely valuableno work can be performed successfully in New Ireland without it. We imagine that it is also possible to monetise this kind of work, although it would be more difficult than in the case of the work outlined in the previous paragraph. The staff can be paid for their time, for the time taken to do the logistical work prior to the visit. However, how could the value of the specialised knowledge required be calculated? How could we do this adequately for each different kind of social situation? Again, a flat or hourly rate of pay might provide a starting point for monetary compensation; however, how could staff expenditure in terms of drawing on their own obligations be repaid? When an obligation is met by people in our imagined village above (an obligation that allows for the visit), how could both the debt that the staff member has relinquished and the newly incurred debt be monetised? How could the long-term engagements that create networks of obligation and exchange be monetised? Finally, and much more importantly, do we want them to be?

Two final forms of work are even more difficult to discuss and, we believe, nearly impossible to monetise or even reciprocate. First, being a 'friendly native' is exhausting work. Over the course of their long collaboration, 
Paige West has watched John Aini do what she would call (and he would not) the 'emotional work of being Indigenous'. This comprises the enacting of a particular form of subjectivity for outsiders that, while adjacent to his subject position as a Maimai (cultural leader or chief), keeper of customary knowledge and tradition, researcher and scholar, father, brother, uncle, grandfather and person fully enmeshed in local, regional, national and international networks of obligation and reciprocity, is also different. For outsiders, he becomes their window into and connection to both his culture and the two other indigenous societies in New Ireland. He becomes more than a 'translator', or what some have called a 'cultural broker'-outsiders view him as the voice of his people. They do not understand the social world underpinning his status and subjectivity; therefore, they see him as a single individual who can 'be native' for them and teach them. John takes this very seriously-he has dedicated his whole life to the health and wellbeing of his people and their biophysical surroundings. How could he be compensated in monetary terms for the work of representing three worlds to outsiders?

Second, for over a decade, John Aini has observed Paige West 'worry'. He says, 'you worry about everything. About all that I go through, about our family, about the people here in New Ireland and their fate'. He has also highlighted that she worries constantly about Ailan Awareness funding, because she is the primary grant writer for the organisation. He says, 'I know you worry that I spend our grant money to help these people, and that makes me worry'. Her work in this regard is not invisible to him or to the many partners of Ailan Awareness across the province. He, and others, understand that she has a good job that pays well; however, they worry that she is continually worried about the NGO and its ability to do work and support all the people who depend on it.

Bruce Robbins identified the kind of modern subject that we have discussed in this chapter in The Beneficiary (2017). By 'beneficiary', Robbins described the modern 'well-meaning' subject who fails to understand their role in the social and ecological inequality they wish to address with their 'work' (Robbins, 2017). He focused on humanitarian aid workers who do not see how their lives of consumption in the Global North are built upon the very social and environmental injustices that they seek to remedy through their waged labour. He argued that they are unaware of (or unable to see) their own role in the structures that cause global suffering and structural inequality, linking this inability to see with a kind of global cosmopolitanism that has existed for generations. 
In this chapter, we have shown how the structural inequality that underpins conservation funding and practice in PNG causes material inequalities that create the conditions in which small NGOs must perform extra work to stay afloat and feel obligated to undertake work and labour that is not strictly part of their organisation's mission. In a structural sense, they are locked into the patron-client relationship with BINGOs and must engage in these if they wish to continue working in PNG. One result of this 'lock in' is that when BINGOs of all kinds (not just conservation-related ones) connect people like Brian to Ailan Awareness, people that we see as beneficiaries, it is nearly impossible for the small NGO to turn them away. To do so would both hurt their relationships with the BINGOs, upon whom they to some extent depend, and cause shame and pain to their staff. This reinforces the already existing structural inequalities discussed at the beginning of this chapter. These well-meaning beneficiaries become a conduit for the ongoing dispossession of Indigenous peoples in PNG, something that we are sure they never meant to be.

\section{Acknowledgements}

The authors' collaboration has been funded by the Christensen Fund, the US Ambassador's Fund for Cultural Preservation, Barnard College and Columbia University. We wish to thank these funders. Our work would not be possible without the countless members of the communities we work with in New Ireland. There are too many people to acknowledge individually, but collectively they are the reason we do this work and our lives are richer because of them. We also wish to thank Cathy Hair, Shaun and Shannon Keane, Matthew Leavesley, Catherine Sparks and Hugh Walton for their ongoing support of Ailan Awareness.

\section{References}

Aini, J. \& Nason, P. (2016, February). A conversation on climate change in the Papua New Guinea Islands. Retrieved from www.envirosociety.org/tag/john-aini/

Aini, J. \& West, P. (2018, June). Communities matter: Decolonizing conservation management. Plenary Lecture presented at the International Marine Conservation Congress, Kuching, Malaysia. 
Aini, J. \& West, P. (n.d.). Beneficiary moves to innocence: Whiteness, power and history in conservation in Papua New Guinea. Unpublished manuscript.

Beer, B. (2018). Gender and inequality in a postcolonial context of large-scale capitalist projects in the Markham Valley, Papua New Guinea. The Australian Journal of Anthropology, 29(3), 348-364.

Bond, C. \& West, P. (2018, May 23). Race, colonialism and the politics of representation. Retrieved from brisbanefreeuniversity.org/2018/05/14/bfupresents-race-colonialism-the-politics-of-representation/

Butcher, J. \& Smith, P. (2015). Volunteer tourism: The lifestyle politics of international development. Abingdon, England: Routledge.

Campbell, L. M., Gray, N. J. \& Meletis, Z. A. (2008). Political ecology perspectives on ecotourism to parks and protected areas. In K. S. Hanna, D. A. Clark \& D. S. Slocombe (Eds), Transforming parks and protected areas: Policy and governance in a changing world (pp. 200-221). Abingdon, England: Routledge.

Campbell, L. M., Haalboom, B. J. \& Trow, J. (2007). Sustainability of communitybased conservation: Sea turtle egg harvesting in Ostional (Costa Rica) ten years later. Environmental Conservation, 34(2), 122-131.

Carrier, J. G. \& West, P. (2009). Virtualism, governance and practice vision and execution in environmental conservation. New York, NY: Berghahn Books.

Chapin, M. (2004). A challenge to conservationists. World Watch Magazine, $17(6), 17-31$.

Cleary, D. B. (2018). What are the grounds needed for dialogue? In P. B. Larsen $\&$ D. Brockington (Eds), The anthropology of conservation NGOs (pp. 251-258). Cham, Switzerland: Palgrave Macmillan.

Connell, J. (2005). Papua New Guinea: The struggle for development. London, England: Routledge.

Conran, M. (2011). They really love me!: Intimacy in volunteer tourism. Annals of Tourism Research, 38(4), 1454-1473.

Fabinyi, M., Foale, S. \& Macintyre, M. (2015). Managing inequality or managing stocks? An ethnographic perspective on the governance of smallscale fisheries. Fish and Fisheries, 16(3), 471-485. doi.org/10.1111/faf.12069

Fitzpatrick, P. (1980). Law and state in Papua New Guinea. London, England: Academic Press. 
Foale, S. \& Macintyre, M. (2005). Green fantasies: Photographic representations of biodiversity and ecotourism in the Western Pacific. Journal of Political Ecology, 12(1), 1-22. doi.org/10.2458/v12i1.21671

Gewertz, D. \& Errington, F. (1999). Emerging class in Papua New Guinea. New York, NY: Cambridge University Press.

Gokkon, B. (2018a, 12 July). 'Decolonising conservation': Q\&A with PNG marine activist John Aini. Retrieved from news.mongabay.com/2018/07/decolonizingconservation-qa-with-png-marine-activist-john-aini/

Gokkon, B. (2018b, 16 July). Protecting PNG's oceans: Q\&A with marine activist John Aini. Retrieved from news.mongabay.com/2018/07/protecting-pngsoceans-qa-with-marine-activist-john-aini/

Gray, N. J. \& Campbell, L. M. (2007). A decommodified experience? Exploring aesthetic, economic and ethical values for volunteer ecotourism in Costa Rica. Journal of Sustainable Tourism, 15(5), 463-482.

Griffiths, M. (2016). An opinion piece. A response to the special issue on volunteer tourism: The performative absence of volunteers. Journal of Sustainable Tourism, 24(2), 169-176. doi.org/10.1080/09669582.2015.1071382

Halvaksz, J. A. (2020). Gardens of gold: Place-making in Papua New Guinea. Seattle, WA: University of Washington Press.

Hathaway, M. J. (2013). Environmental winds: Making the global in Southwest China. Berkeley, CA: University of California Press.

Henry, J. (2019). The unspeakable whiteness of volunteer tourism. Annals of Tourism Research, 76, 326-327. doi.org/10.1016/j.annals.2018.09.003

Johnson, P. L. (1993). Education and the 'new' inequality in Papua New Guinea. Anthropology and Education Quarterly, 24(3), 183-204.

Josephides, L. (1985). The production of inequality: Gender and exchange among the Kewa. New York, NY: Taylor \& Francis.

Kelly, R. C. (1993). Constructing inequality: The fabrication of a hierarchy of virtue among the Etoro. Ann Arbor, MI: University of Michigan Press.

Laarman, J. G. \& Perdue, R. R. (1989). Science tourism in Costa Rica. Annals of Tourism Research, 16(2), 205-215.

Lowe, C. (2006). Wild profusion: Biodiversity conservation in an Indonesian archipelago. Princeton, NJ: Princeton University Press. 
Moore, A. (2019). Destination anthropocene: Science and tourism in the Bahamas. Durham, NC: Duke University Press. doi.org/10.2307/j.ctvpb3wqz

Nason, P. (2018). Sounding sovereignty: The politics of presence in the Bismarck Archipelago (Unpublished doctoral thesis). Colombia University, New York.

Robbins, B. (2017). The beneficiary. Durham, NC: Duke University Press.

Roberts, J. (2019a). We stay the same': Life logging and the continuing pursuit of development on New Hanover Island (Lovangai), Papua New Guinea (Unpublished doctoral thesis). Department of Anthropology, University of Texas, San Antonio.

Roberts, J. (2019b). 'We live like this': Local inequalities and disproportionate risk in the context of extractive development and climate change on New Hanover Island, Papua New Guinea. Oceania, 88(3), 68-88.

Ryan, S., Curry, G. N., Germis, E., Koczberski, G. \& Koia, M. (2016). Challenges to the democratisation of knowledge: Status hierarchies and emerging inequalities in educational opportunities amongst oil palm settlers in Papua New Guinea. In M. Robertson \& P. K. E. Tsang (Eds), Everyday knowledge, education and sustainable futures: Transdisciplinary approaches in the Asia-Pacific Region (pp. 123-139). Singapore: Springer.

Sodikoff, G. (2009). The low-wage conservationist: Biodiversity and perversities of value in Madagascar. American Anthropologist, 111(4), 443-455. doi.org/ 10.1111/j.1548-1433.2009.01154.x

Sodikoff, G. (2012). Forest and labour in Madagascar: From colonial concession to global biosphere. Bloomington, IN: Indiana University Press.

Stella, R. T. (2007). Imagining the other: The representation of the Papua New Guinean. Honolulu, HI: University of Hawai'i Press.

Strathern, A. (1982). Inequality in New Guinea Highlands societies. Cambridge, England: Cambridge University Press.

Van Helden, F. (1998). Between cash and conviction: The social context of the Bismarck-Ramu integrated conservation and development project. Boroko, Papua New Guinea: National Research Institute.

Vivanco, L. A. (2007). Green encounters: Shaping and contesting environmentalism in rural Costa Rica. New York, NY: Berghahn Books.

Wagner, J. (2007). Conservation as development in Papua New Guinea: The view from Blue Mountain. Human Organization, 66(1), 28-37. doi.org/10.17730/ humo.66.1.q21q23v06t374204 
Wahlen, C. B. (2013). The anomalous is ubiquitous: Organisations and individuals in Papua New Guinea's conservation efforts (Unpublished doctoral thesis). University of Michigan, Ann Arbor.

Wardlow, H. (2006). Wayward women: Sexuality and agency in a New Guinea society. Berkley, CA: University of California Press.

West, P. (2006). Conservation is our government now: The politics of ecology in Papua New Guinea. Durham, NC: Duke University Press.

West, P. (2008). Tourism as science and science as tourism: Environment, society, self, and other in Papua New Guinea [with Comments]. Current Anthropology, 49(4), 597-625. doi.org/10.2307/20142693

West, P. (2012). From modern production to imagined primitive: The social world of coffee from Papua New Guinea. Durham, NC: Duke University Press.

West, P. (2016). Dispossession and the environment: Rhetoric and inequality in Papua New Guinea. New York, NY: Columbia University Press.

West, P. \& Aini, J. (2018, June). Critical approaches to dispossession in the Melanesian Pacific: Conservation, voice and Collaboration. Keynote Lecture, presented at the POLLEN 2018 Political Ecology Network Biennial Conference, Oslo, Norway.

Zimmer-Tamakoshi, L. (2016). Inequality and changing masculinities among the Gende in Papua New Guinea: The 'good', the 'bad' and the 'very bad'. The Asia Pacific Journal of Anthropology, 17(3-4), 250-267. 
This text is taken from Unequal Lives: Gender, Race and Class in the Western Pacific, edited by Nicholas A. Bainton, Debra McDougall, Kalissa Alexeyeff and John Cox, published 2021 by ANU Press, The Australian National University, Canberra, Australia.

doi.org/10.22459/UE.2020.02 